\title{
BesEARCA IN S

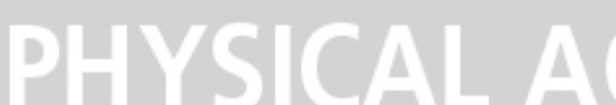

Fatiguing exercise alters leukocyte subpopulation frequency in the bone marrow and peripheral blood in C57BL/6 mice

\author{
Oliveira, Daniela Silva De; Lopes, Laís Roquete; Souza, Débora Maria \\ Autor(es): $\quad$ Soares de; Rezende, Barbara Maximino; Silva, Vanessa Pinho da; \\ Talvani, André; Nunes-Silva, Albená
}

Publicado por: Imprensa da Universidade de Coimbra

URL

persistente:

URI:http://hdl.handle.net/10316.2/44144

DOI:

DOI:https://doi.org/10.14195/2182-7087_ex2018_81

Accessed : $\quad$ 26-Apr-2023 12:12:48

A navegação consulta e descarregamento dos títulos inseridos nas Bibliotecas Digitais UC Digitalis, UC Pombalina e UC Impactum, pressupõem a aceitação plena e sem reservas dos Termos e Condições de Uso destas Bibliotecas Digitais, disponíveis em https://digitalis.uc.pt/pt-pt/termos.

Conforme exposto nos referidos Termos e Condições de Uso, o descarregamento de títulos de acesso restrito requer uma licença válida de autorização devendo o utilizador aceder ao(s) documento(s) a partir de um endereço de IP da instituição detentora da supramencionada licença.

Ao utilizador é apenas permitido o descarregamento para uso pessoal, pelo que o emprego do(s) título(s) descarregado(s) para outro fim, designadamente comercial, carece de autorização do respetivo autor ou editor da obra.

Na medida em que todas as obras da UC Digitalis se encontram protegidas pelo Código do Direito de Autor e Direitos Conexos e demais legislação aplicável, toda a cópia, parcial ou total, deste documento, nos casos em que é legalmente admitida, deverá conter ou fazer-se acompanhar por este aviso. 


\section{ANNALS OF RESEARCH IN SPORT AND PHYSICAL ACTIVITY}




\section{FATIGUING EXERCISE ALTERS LEUKOCYTE SUBPOPULATION FREQUENCY IN THE BONE MARROW AND PERIPHERAL BLOOD IN C57BL/6 MICE}

Daniela Silva De Oliveira'; Laís Roquete Lopes'; Débora Maria Soares de Souza1; Barbara Maximino Rezendez; Vanessa Pinho da Silva²; André Talvani'; Albená Nunes-Silva

KEYWORDS: physical exercise, immune function, leukocytes.

Previous studies have demonstrated the influence of intense exercise on immune function including changes in the population of leukocytes such as neutrophils, lymphocytes and monocytes on the blood circulation. A common finding is that the numbers of leukocytes subpopulation alters after different protocols of exercise.

\section{AIM}

Here, we investigated the effects of progressive fatiguing exercise protocol on the leukocytes frequency on the blood circulation and in the bone marrow in the C57BL/6.

\section{METHODS}

An electric treadmill was used for the fatiguing exercise protocol. The initial speed was set at 5 meters per minute $(\mathrm{m} / \mathrm{min})$ for 30 minutes to familiarize the mice with the appa-

\footnotetext{
${ }^{1}$ Universidade Federal de Ouro Preto.

2 Universidade Federal de Minas Gerais.
}

Email: albenanunes@hotmail.com; danielasilva94@live.com; laisroquete@hotmail.com; souza.debora@ymail. com; barbaramaximinorez@gmail.com; vpinhos@gmail.com; talvani72@gmail.com 
ratus and task. The speed was then increased $1 \mathrm{~m} / \mathrm{min}$ every $3 \mathrm{~min}$, at a $5 \%$ grade, until the animal stopped running and was fatigued, which was judged by the refusal of the mouse to continue moving on the treadmill belt more than 10 seconds. The control group did not perform fatiguing exercise protocol and exercised group exercised until fatigue by running for $56.3 \pm 6.8 \mathrm{~min}$. Blood and bone marrow were collected by $1 \mathrm{~h}$ after the end of exercise and analyzed in flow cytometry for the following markers: Ly6C-monocytes, Ly6Gneutrophils and CD3-T cells.

\section{RESULTS}

The results show that after 1 hour of the end of fatiguing exercise protocol, C57BL/6 mice, there was an increase in the frequency of neutrophils (from $22.8 \%$ to $48.6 \%$ ) and monocytes (from $34.8 \%$ to $70.5 \%$ ) in the blood while there was elevation of the lymphocyte population (from $5.5 \%$ to $8.1 \%$ ) in the bone marrow. We believe that this profile may undergo modifications in later times and we are working in this proposal. Conclusion: Taken together, these results suggested that the fatiguing exercise protocols induces immunological changes and provokes significant, although transient, modulation of the immune system, specifically of the leukocyte sub-population. 